\title{
Site-selective solid phase synthesis of carbonylated peptides
}

\author{
Mateusz Waliczek $^{1} \cdot$ Monika Kijewska $^{1} \cdot$ Piotr Stefanowicz $^{1} \cdot$ Zbigniew Szewczuk $^{1}$
}

Received: 2 December 2014 / Accepted: 17 March 2015 / Published online: 27 March 2015

(C) The Author(s) 2015. This article is published with open access at Springerlink.com

\begin{abstract}
The aim of our research was to design an efficient method for the solid phase synthesis of carbonylated peptides. For this purpose, we designed and synthesized a fully protected derivative Fmoc-amino(2,5,5-trimetyhyl1,3-dioxolan-2-yl)acetic acid (Fmoc-Atda-OH) of a novel unnatural amino acid $(\operatorname{Thr}(\mathrm{O})$-2-amino-3-oxo-butanoic acid). To obtain the mentioned derivative, two synthetic strategies were investigated using different reagents for carbonyl protection, ethane-1,2-diol and 2,2-dimethyl-propane-1,3-diol. The racemization of oxidized threonine was also analyzed and discussed. We successfully carried out the solid phase synthesis of peptides containing a $\operatorname{Thr}(\mathrm{O})$ moiety using Fmoc-Atda-OH according to the standard Fmoc strategy. The application of the designed building block allows the synthesis of peptides containing D,L$\operatorname{Thr}(\mathrm{O})$ residue, which may be used as models of oxidatively modified peptides which occur in biological systems and are related to many diseases.
\end{abstract}

Keywords Oxidative stress · Oxidation - Carbonylation · Solid phase peptide synthesis - Carbonylated peptides . Posttranslational modification

Handling Editor: J. Bode.

Electronic supplementary material The online version of this article (doi:10.1007/s00726-015-1967-4) contains supplementary material, which is available to authorized users.

Monika Kijewska

monika.kijewska@chem.uni.wroc.pl

1 Faculty of Chemistry, University of Wrocław, F. Joliot-Curie 14, 50-383 Wrocław, Poland

\section{Introduction}

The Reactive Oxygen Species (ROS) formation is the consequence of a redox regulation in cells (Madian and Regnier 2010a). The impaired balance between production and removing ROS is an undesirable phenomenon that can lead not only to oxidation of proteins but also other biomolecules, like DNA, fatty acids, and carbohydrates. The proteins, however, are the most susceptible to ROS impact. Many changes in amino acid residues resulting from oxidation reactions have been characterized, such as carbonylation or disulfide formation (Madian and Regnier 2010b). The selected examples are presented in Table 1 (Madian and Regnier 2010a). These post-translational modifications can be divided into three groups distinguishable by mass spectrometry. One involves oxidative cleavage in either the protein backbone or amino acid side chains, with Pro, Arg, Lys, Thr, Glu or Asp residues most likely to undergo oxidative cleavage. The Cys and Met are most susceptible to oxidative modification. Other moieties, especially Lys, Arg, Pro and Thr incur formation of carbonyl groups (aldehydes and ketones) in the side chains. This modification is based on the addition of lipid oxidation products such as 4-hydroxy-2-nonenal to proteins. Finally, carbonyl groups in proteins can be generated by advanced glycation.

Some of these oxidations are reversible and can play a role in metabolism, the other-irreversible-often lead to protein inactivation. Protein carbonylation is considered to be the most common protein oxidation reaction, therefore, it has become an indicator of the oxidative stress (Moller and Rogowska-Wrzesińska 2011; Roe et al. 2010). It has been proven that metal-catalyzed oxidation (MCO) is the main mechanism of protein carbonylation. The other pathways leading to formation of carbonyl moieties involve 
Table 1 List of the different types of oxidative modifications (Madian and Regnier 2010a)

\begin{tabular}{ll}
\hline Amino acids & Oxidative modification \\
\hline $\mathrm{T}$ & 2-Amino-3-oxo-butanoic acid \\
$\mathrm{Y}, \mathrm{D}, \mathrm{K}, \mathrm{F}, \mathrm{P}$ & Hydroxylation \\
$\mathrm{K}$ & Aminoadipic semialdehyde, Amadori products, \\
& 3-Deoxyglucosone adducts, glyoxal adducts, \\
& methylglyoxal adducts, hydroxynonenal, \\
& malonodialdehyde, $N$-homocysteinylation \\
$\mathrm{R}$ & Glutamic semialdehyde \\
$\mathrm{C}$ & Sulfonic acid, sulfinic acid, sulfenic acid, \\
$\mathrm{M}$ & S-homocysteinylation \\
$\mathrm{P}$ & Sulfoxide, sulfon \\
\hline
\end{tabular}

either oxidative cleavage of proteins by $\alpha$-amidation pathway or oxidation of glutamyl side chains (Stadtman and Levine 2003; Requena et al. 2001). An addition of 4-hydroxynoneal, the main product of lipid peroxidation, to nucleophilic groups in the side chains of amino acids is another mechanism leading to formation of the carbonylated proteins (Dalle-Donne et al. 2006). This posttranslational modification (PTM) is linked to numerous diseases, including diabetes (Telci et al. 2000), cancer or Parkinson and Alzheimer diseases (Smith et al. 1991; Uttara et al. 2009).

Characterization of carbonylated proteins has been a challenge for contemporary proteomics due to their low abundance in the biological material as well as a diversity of possible modifications resulting from various pathways leading to the carbonyl compound formation. Because of the requirements imposed by proteomics, many useful methods allowing selecting and recognizing the carbonylated proteins have emerged. Most of these techniques are based on formation of Schiff bases (Dalle-Donne et al. 2005; Grimsrud et al. 2008) ranging from the classic dinitrophenylhydrazine derivatization (DNPH) (Palmese et al. 2011), through biotin hydrazide (Mirzaei et al. 2008) method to Girard's P reagent (Mirzaei and Regnier 2006) and Oxidation-Dependent Element Coded Affinity Tags (O-ECAT) (Lee et al. 2006). The widely used enrichment approach consists reaction of the carbonyl group with biotin hydrazide and a further selection, by means of immobilized avidin or streptavidin on an affinity column (Mirzaei et al. 2008). The additional advantage of Girard's P reagent, which is also based on hydrazone formation, is an increase in ionization efficiency resulting from the presence of a permanent positive charge in the quaternary ammonium moiety (Mirzaei and Regnier 2006). The high-resolution mass spectrometry combined with stable isotope labeling involving specific incorporation of ${ }^{18} \mathrm{O}$ into the carbonyl moieties is also used for studying carbonylated proteins.
The resulting isotopic signature observed in a mass spectrum allows detection of carbonylated peptides (Roe et al. 2010). Similarly, it was proven that treating the sample containing glycated peptides with $\mathrm{H}_{2}^{18} \mathrm{O}$ under microwave activation, results in the isotopic exchange of anomeric oxygen which allows detection of the Amadori products by MS techniques (Kijewska et al. 2011). DNPH derivatized carbonylated peptides were also analyzed by ESI-MS/MS in the negative ion mode allowing a differentiation of various types of carbonyl compounds through a specific fragmentation (Bollineni et al. 2011a).

In view of the reasons given above, there is a need for new methods of carbonylated peptide synthesis, since they are useful as standards for quantitative analysis and help in development of enrichment methods. Actually, the available methods allow only for synthesis of model unnatural carbonylated peptides. Marceau (2005) and co-workers (Buré et al. 2012; Bollineni et al. 2011b) reported synthesis of the C-terminal alpha-oxo aldehyde peptides and pyruvic acid-containing peptides using solid phase synthesis. Another approach, based on periodate oxidation of 2-aminoalcohol (for example serine or threonine), results in formation of the aldehyde group at the N-terminus of a peptide chain.

The objective of our current work is a synthesis of peptides containing oxidized threonine using a fully protected building block. This approach allows preparation of analytically pure product containing $\operatorname{Thr}(\mathrm{O})$ residue. According to literature reports (Madian and Regnier 2010b), such peptides were detected in products of enzymatic hydrolysis of oxidized proteins. This synthetic approach is similar to that applied in our previous paper, focused on the reaction of a lysine moiety with reducing sugars (Stefanowicz et al. 2010). In the current project, we extended our research to the physiologically relevant oxidative modifications resulting in carbonylation of proteins. It may be expected that these model compounds will be useful for development and testing affinity-based procedures of preconcentration of carbonylated peptides. In addition, isotopically labeled analytically pure peptides containing carbonyl groups may be used for the quantitative determination of this modification in enzymatic digests.

\section{Experimental}

\section{Reagents}

Z-Thr-OBzl ( $>98 \%)$ was purchased from Alfa Aesar (Karlsruhe, Germany). The oxidizing agents: pyridinium chlorochromate (PCC) was obtained from Sigma-Aldrich (St. Louis, MO, USA) and sulfur trioxide-pyridine complex was obtained from Fluka (Steinheim, Germany). The 
solvents used for Fmoc-Amda-OH synthesis were: dichloromethane (Chempur, Piekary Śląskie, Poland), dimethyl sulfoxide (Scientific Limited Park, Northapton, U.K), methanol (POCh, Poland), ethanol (Eurochem BGD), acetone (POCh, Poland), benzene (Eurochem BGD, Tarnów, Poland) and diethyl ether (Chempur, Poland). Ethylene glycol, 2,2-dimethyl-propane-1,3-diol and $p$-toluenesulfonic acid as a catalyst were obtained from Sigma-Aldrich (St. Louis, MO, USA). The protecting group 9-fluorenylmethyl succinimidyl carbonate (Fmoc-OSu) was purchased from Iris Biotech GmbH (Marktredwitz, Germany). Ethyl acetoacetate as a starting substrate in Method 2 was from Sigma-Aldrich (St. Louis, MO, USA). The zinc dust and $\mathrm{N}, \mathrm{N}$-diisopropylethylamine were purchased from Fluka (Steinheim, Germany). Sodium nitrite was obtained from POCh and glacial acetic acid from J. T. Baker (Deventer, The Netherlands). The inorganic salts such as potassium hydrogen sulfate and anhydrous magnesium sulfate were purchased from Chempur. The solvents for peptide synthesis (analytical grade) were obtained from Riedel de Haën (Seelze, Germany) (DMF) and J. T. Baker (methanol).

\section{Synthesis of Fmoc-amino(2-metyhyl-1,3-dioxolan-2-yl) acetic acid (Method 1A) and Fmoc-amino(2,5,5-trimetyhyl-1,3-dioxolan-2-yl) acetic acid (Method 1B)}

\section{Method 1A}

Synthesis of Z-Thr $(O)$-OBzl (1) Oxidation 1 Z-ThrOBzl (0.5 g, $1.5 \mathrm{mmol})$ was dissolved in dichloromethane $(40 \mathrm{ml})$. After the addition of PCC $(0.69 \mathrm{~g}, 0.32 \mathrm{mmol})$ and molecular sieves $(3 \mathrm{~g})$, the resulting mixture was stirred for $24 \mathrm{~h}$. After this time, the mixture was diluted with diethyl ether $(100 \mathrm{ml})$ and filtered through a short column containing silica gel and evaporated to dryness.

HPLC: retention time (min): 35.7 (conditions for HPLC are given in the "Experimental" section). HR-MS $\mathrm{m} / \mathrm{z}$ : found 364.128 calculated for $\left(\mathrm{C}_{19} \mathrm{H}_{19} \mathrm{NO}_{5}+\mathrm{Na}\right)^{+} 364.116$.

Oxidation 2 Z-Thr-OBzl (0.5 g, $1.5 \mathrm{mmol})$ was dissolved in dichloromethane $(5 \mathrm{ml})$ and then triethylamine $(0.6 \mathrm{ml}$. $4.3 \mathrm{mmol}$ ) was added. The mixture was cooled to $-10{ }^{\circ} \mathrm{C}$ in the ice bath. The next step included addition of the $\mathrm{SO}_{3} /$ pyridine complex in freshly distilled DMSO $(5 \mathrm{ml})$. The resulting mixture was stirred for $2.5 \mathrm{~h}$. The progress of the reaction was controlled using TLC (eluent: E2). After the reaction completion, water $(20 \mathrm{ml})$ with potassium hydrogen sulfate was added to increase the salting-out effect. Then, the mixture was extracted with ethyl acetate $(15 \mathrm{ml})$ and the organic layer was washed with water and brine. The combined organic extracts were dried over anhydrous $\mathrm{MgSO}_{4}$ and evaporated to dryness.
HPLC: retention time (min): 35.6 (conditions for HPLC are given in the "Experimental" section). HR-MS $\mathrm{m} / \mathrm{z}$ : found 364.127 calculated for $\left(\mathrm{C}_{19} \mathrm{H}_{19} \mathrm{NO}_{5}+\mathrm{Na}\right)^{+} 364.116$.

Synthesis of Z-Thr(Amda)-OBzl (2) The crude, oxidized product $(0.51 \mathrm{~g}, 1.5 \mathrm{mmol})$ was dissolved in benzene $(60 \mathrm{ml})$. To this mixture, ethylene glycol $(0.36 \mathrm{~g}, 5.8 \mathrm{mmol})$ and $p$-toluenesulfonic acid $(120 \mathrm{mg}$ ) (as a catalyst) were added (Green and Wuts 1999). The resulting mixture was refluxed for $2.5 \mathrm{~h}$ using a Dean-Stark apparatus to remove water. After the reaction completion, the solvent was evaporated under reduced pressure. HR-MS $\mathrm{m} / \mathrm{z}$ : found 408.141 calculated for $\left(\mathrm{C}_{21} \mathrm{H}_{23} \mathrm{NO}_{6}+\mathrm{Na}\right)^{+} 408.142$.

Synthesis of Fmoc-Thr(Amda)-OH (3) To remove protecting groups, the obtained crude product was subjected to hydrogenolysis in methanol, using $5 \% \mathrm{Pd}$ on charcoal as a catalyst. The reduction was carried out for $4 \mathrm{~h}$ and the reaction progress was controlled with TLC (eluent: E2). Then, the mixture was filtered through a paper filter and evaporated to dryness.

TLC: retention time $R_{\mathrm{f}}: 0.19$ (conditions for TLC are given in the "Experimental" section). HR-MS $m / z$ : found 162.083 calculated for $\left(\mathrm{C}_{6} \mathrm{H}_{11} \mathrm{NO}_{4}+\mathrm{H}\right)^{+} 162.076$.

The last step included introduction of the fluorenylmethoxycarbonyl group (Fmoc). For this purpose, the crude product $(1.5 \mathrm{mmol})$ was dissolved in water $(15 \mathrm{ml})$ and brought to $\mathrm{pH} 8$ with $\mathrm{NaHCO}_{3}$. After determination of the $\mathrm{pH}, \mathrm{Fmoc}-\mathrm{OSu}(0.49 \mathrm{~g}, 1.5 \mathrm{mmol})$ was added. Due to the precipitation, the stoichiometric amount of DIEA $(0.25 \mathrm{ml})$ in acetone $(15 \mathrm{ml})$ was added. The reaction progress was controlled using TLC (eluent: E1). After the reaction completion, acetone was removed using a rotary evaporator. The remaining solution was acidified using potassium hydrogen sulfate and then extracted with ethyl acetate $(30 \mathrm{ml})$, and washed with water. Finally, the combined organic layers were dried over anhydrous magnesium sulfate and evaporated to dryness.

Fmoc-Amda-OH yield: $25 \%$; HPLC: retention time (min): 33.3 (conditions for HPLC are given in the "Experimental" section). HR-MS $\mathrm{m} / \mathrm{z}$ : found 406.126 calculated for $\left(\mathrm{C}_{21} \mathrm{H}_{21} \mathrm{NO}_{6}+\mathrm{Na}\right)^{+}$406.126; MS/MS (parent 406.126): 362.148 .

Fmoc-BAla-OH HPLC: retention time (min): 32.5 (conditions for HPLC are given in the "Experimental" section). HR-MS $\mathrm{m} / \mathrm{z}$ : found 334.105 calculated for $\left(\mathrm{C}_{17} \mathrm{H}_{18} \mathrm{NO}_{4}+\mathrm{Na}\right)^{+} 334.105 ;{ }^{1} \mathrm{H}$ NMR $\left(\mathrm{CDCl}_{3}\right) \delta$ $(\mathrm{ppm})=7.74(\mathrm{~d}, \mathrm{~J}=7.5 \mathrm{~Hz}, 2 \mathrm{H}), 7.56(\mathrm{~d}, \mathrm{~J}=7.4 \mathrm{~Hz}$, $2 \mathrm{H}), 7.38(\mathrm{t}, \mathrm{J}=7.4 \mathrm{~Hz}, 2 \mathrm{H}), 7.29(\mathrm{t}, \mathrm{J}=7.3 \mathrm{~Hz}, 2 \mathrm{H})$, $5.25(\mathrm{~s}, 1 \mathrm{H}), 4.42(\mathrm{~m}, 2 \mathrm{H}), 3.42(\mathrm{~m}, 2 \mathrm{H}), 2.50(\mathrm{~m}, 2 \mathrm{H}) ;{ }^{13} \mathrm{C}$ NMR $\left(\mathrm{CDCl}_{3}\right) \delta(\mathrm{ppm})=176.93,156.58,143.96,141.55$, $127.93,127.27,125.29,120.22,67.03,47.43,36.55,34.30$. 


\section{Method $1 B$}

Synthesis of Z-Thr(Atda)-OBzl (2) This procedure included the same synthetic step as described in Method 1A. As a protecting group, 2,2,-dimetylopropan-1,3-diol was used. The crude, oxidized product $(0.51 \mathrm{~g}, 1.5 \mathrm{mmol})$ was dissolved in toluene $(60 \mathrm{ml})$ and then, 2,2,-dimetylopropan1,3-diol $(0.60 \mathrm{~g}, 5.8 \mathrm{mmol})$ was added to this mixture with $p$-toluenesulfonic acid $(120 \mathrm{mg})$ as a catalyst. The resulting mixture was refluxed for $2.5 \mathrm{~h}$ using a Dean-Stark apparatus to remove water. After the reaction completion, the solvent was evaporated under reduced pressure. HR-MS $\mathrm{m} / \mathrm{z}$ : found 450.193 calculated for $\left(\mathrm{C}_{24} \mathrm{H}_{29} \mathrm{NO}_{6}+\mathrm{Na}\right)^{+} 450.188$.

Synthesis of Fmoc-Thr(Atda)-OH (3) The last two steps consisted of hydrogenolysis and introduction of the Fmoc group as described in Method 1A. Finally, the reaction product was purified by chromatography on a silica gel. Impurities were eluted first using chloroform containing $3 \%$ of methanol, then, the reaction product was eluted using chloroform containing $3 \%$ of methanol and $0.15 \%$ of acetic acid.

Yield: $60 \%$; HPLC: retention time (min): 31.5 (conditions for HPLC are given in the "Experimental" section). HR-MS $\mathrm{m} / \mathrm{z}$ : found 448.172 calculated for $\left(\mathrm{C}_{24} \mathrm{H}_{27} \mathrm{NO}_{6}+\mathrm{Na}\right)^{+}$448.173; MS/MS (parent 448.171): 404.182; ${ }^{1} \mathrm{H}$ NMR $\left(\mathrm{CDCl}_{3}\right) \delta(\mathrm{ppm})=7.74(\mathrm{~d}, \mathrm{~J}=7.5 \mathrm{~Hz}$, 2H), $7.58(\mathrm{t}, \mathrm{J}=7.2 \mathrm{~Hz}, 2 \mathrm{H}), 7.37(\mathrm{t}, \mathrm{J}=7.4 \mathrm{~Hz}, 2 \mathrm{H}), 7.29$ $(\mathrm{td}, \mathrm{J}=7.4 \mathrm{~Hz}, 0.9 \mathrm{~Hz}, 2 \mathrm{H}), 5.62(\mathrm{~d}, \mathrm{~J}=9.1 \mathrm{~Hz}, 1 \mathrm{H}), 4.63$ $(\mathrm{d}, \mathrm{J}=9.3 \mathrm{~Hz}, 1 \mathrm{H}), 4.39(\mathrm{p}, \mathrm{J}=10.6 \mathrm{~Hz}, 2 \mathrm{H}), 4.22(\mathrm{t}$, $\mathrm{J}=7.1 \mathrm{~Hz}, 1 \mathrm{H}), 3.67(\mathrm{dd}, \mathrm{J}=45.9 \mathrm{~Hz}, 11.5 \mathrm{~Hz}, 2 \mathrm{H}), 3.55$ $(\mathrm{dd}, \mathrm{J}=45.9 \mathrm{~Hz}, 11.5 \mathrm{~Hz}, 2 \mathrm{H}), 1.51(\mathrm{~s}, 3 \mathrm{H}), 1.10(\mathrm{~s}, 3 \mathrm{H})$, $0.82(\mathrm{~s}, 3 \mathrm{H}) ;{ }^{13} \mathrm{C} \mathrm{NMR}\left(\mathrm{CDCl}_{3}\right) \delta(\mathrm{ppm})=171.01,156.55$, $143.97,141.50,127.32,127.29,125.38,120.17,70.26$, $70.23,67.65,59.87,47.31,30.24,23.13,22.56,16.57$.

\section{Synthesis}

\section{of Fmoc-amino(2,5,5-trimetyhyl-1,3-dioxolan-2-yl) acetic acid (Method 2)}

\section{Synthesis of Ac-Thr $(O)-O E t\left(I^{*}\right)$}

Ethyl acetoacetate (1 g, $7.63 \mathrm{mmol})$ was placed in twonecked, round bottom flask equipped with a thermometer and a magnetic stirrer. After cooling in the ice bath, glacial acetic acid $(1.4 \mathrm{ml})$ and water $(2 \mathrm{ml})$ were added with stirring. Sodium nitrite $(1.58 \mathrm{~g}, 45.8 \mathrm{mmol})$ was added in portions over $1.5 \mathrm{~h}$ with the temperature kept constant at about $5{ }^{\circ} \mathrm{C}$. Then, the ice bath was removed and the stirring was continued for $4 \mathrm{~h}$. At that time, the temperature increased to $34-38{ }^{\circ} \mathrm{C}$ within $2 \mathrm{~h}$ and then decreased to about $29^{\circ} \mathrm{C}$. The reaction product was extracted with diethyl ether $(3 \times 10 \mathrm{ml})$. The combined organic layers were used directly in the next step. The obtained ether solution containing acetic anhydride $(2.1 \mathrm{~g}, 20.6 \mathrm{mmol})$ and glacial acetic acid $(5.78 \mathrm{~g}, 96.2 \mathrm{mmol})$ was placed in two-necked, round bottom flask equipped with thermometer. Then, the zinc dust $(1.92 \mathrm{~g}, 293 \mathrm{mmol})$ was added in small portions over a period of $1.5 \mathrm{~h}$ with vigorous stirring at temperature in the range of $40-50{ }^{\circ} \mathrm{C}$. The exothermic reaction was cooled in a water bath. After completion of the metal addition, the mixture was stirred for an additional $30 \mathrm{~min}$. The excess zinc powder was filtered and washed thoroughly with three $10 \mathrm{ml}$ portions of glacial acetic acid. The resulting filtrate was evaporated under reduced pressure and finally, thick oil was obtained.

HPLC: retention time (min): 8.8 (conditions for HPLC are given in the "Experimental" section). HR-MS $\mathrm{m} / \mathrm{z}$ : found 210.081 calculated for $\left(\mathrm{C}_{8} \mathrm{H}_{13} \mathrm{NO}_{4}+\mathrm{Na}\right)^{+} 210.074$; ${ }^{1} \mathrm{H} \mathrm{NMR}\left(\mathrm{CDCl}_{3}\right) \delta(\mathrm{ppm})=1.29(\mathrm{t}, \mathrm{J}=7.1 \mathrm{~Hz}, 3 \mathrm{H}), 2.04$ (s, 3H), $2.36(\mathrm{~s}, 3 \mathrm{H}), 4.25(\mathrm{qd}, \mathrm{J}=6.0 \mathrm{~Hz}, 3.0 \mathrm{~Hz}, 2 \mathrm{H})$, $5.22(\mathrm{~d}, \mathrm{~J}=6.5,1 \mathrm{H}) ;{ }^{13} \mathrm{C} \mathrm{NMR}\left(\mathrm{CDCl}_{3}\right) \delta(\mathrm{ppm})=14.19$, 28.33, 62.88, 63.37, 166.30, 170.09, 198.87 .

\section{Synthesis of Ac-Thr(Atda)-OEt $(2 *)$}

The carbonylated product $(0.5 \mathrm{~g}, 2.6 \mathrm{mmol})$ was dissolved in toluene $(60 \mathrm{ml})$ and 2,2-dimethyl-propane-1,3-diol $(1.08 \mathrm{~g}, 10.3 \mathrm{mmol})$, and $p$-toluenesulfonic acid as a catalyst $(150 \mathrm{mg})$ were added. The resulting mixture was refluxed for $2.5 \mathrm{~h}$ using a Dean-Stark apparatus. After the reaction completion, the solvent was evaporated under reduced pressure (Green and Wuts 1999). HR-MS m/z: found 296.141 calculated for $\left(\mathrm{C}_{13} \mathrm{H}_{23} \mathrm{NO}_{5}+\mathrm{Na}\right)^{+} 296.147$.

\section{Synthesis of Fmoc-Thr(Atda)-OH (3*)}

To remove the $\mathrm{C}$ and $\mathrm{N}$ protecting groups, the alkaline hydrolysis with $3.5 \mathrm{M} \mathrm{NaOH}$ was carried out for $48 \mathrm{~h}$. The reaction was controlled with a ninhydrin test. After the hydrolysis was completed, the resulting strongly alkaline mixture was used in the next step. It was brought to $\mathrm{pH} 8$ with concentrated hydrochloric acid and treated with Fmoc$\mathrm{OSu}(0.90 \mathrm{~g}, 2.56 \mathrm{mmol})$ in acetone, to reach the conditions for introducing the Fmoc-protecting group described in this paper (Method 1A or 1B). Finally, the reaction product was purified as described in Method 1B.

Yield: $60 \%$; HPLC: retention time ( $\mathrm{min}$ ): 31.5 (conditions for HPLC are given in the Experimental section). HR-MS $m / z$ : found 448.173 calculated for $\left(\mathrm{C}_{24} \mathrm{H}_{27} \mathrm{NO}_{6}+\mathrm{Na}\right)^{+}$ 448.173; MS/MS (parent 448.173) 404.180.

\section{Peptide preparation}

The model peptides were prepared on a solid support according to the standard Fmoc protocol (Chan and White 
2000). The coupling of respective amino acid residues was carried out using TCTU in DMF. The acetal protection of the carbonyl group was removed simultaneously with the peptide cleavage from the resin, using TFA/ $\mathrm{H}_{2} \mathrm{O} / \mathrm{TIS}$ $(95: 2.5: 2.5, \mathrm{v} / \mathrm{v})$ for $3 \mathrm{~h}$ at room temperature, resulting in a carbonylated peptide.

\section{Purification and characterization of peptides}

The crude peptide products after releasing from the resin were analyzed using a Thermo Separation HPLC system with a UV detection $(210 \mathrm{~nm})$ on a Vydac Protein RP C18 column $(4.6 \times 250 \mathrm{~mm}, 5 \mu \mathrm{m})$, with a gradient elution of $0-80 \% \mathrm{~S} 2$ in $\mathrm{S} 1\left(\mathrm{~S} 1=0.1 \%\right.$ aqueous TFA in $\mathrm{H}_{2} \mathrm{O}$; $\mathrm{S} 2=80 \%$ acetonitrile $+0.1 \% \mathrm{TFA}$ ) for $40 \mathrm{~min}$ (flow rate $1 \mathrm{ml} / \mathrm{min}$ ). The main carbonylated product was purified using preparative reversed-phase HPLC on a TOSOH Bioscience TSKgel ODS 120T column $(21.5 \mathrm{~mm} \times 300 \mathrm{~mm}$; $10 \mu \mathrm{m})$, using eluent systems: S1 $0.1 \%$ aqueous TFA, S2 $80 \%$ acetonitrile $+0.1 \%$ TFA, linear gradient from 50 to $100 \%$ of S2 for $40 \mathrm{~min}$, flow rate $7.0 \mathrm{ml} / \mathrm{min}$, UV detection at $220 \mathrm{~nm}$. The resulting fractions were collected and lyophilized. The identities of the products were confirmed by MS analysis using a microTOF-Q mass spectrometer equipped with an electrospray ionization source.

\section{TLC analysis}

The reactions described in this paper were controlled using TLC. This procedure was performed using TLC plates (Precoated TLC plates ALUGRAM ${ }^{\circledR}$ SIL G/UV $254,5 \times 10 \mathrm{~cm}$ ) and eluent systems: $n$-buthyl alcohol:acetic acid:water (4:1:1) as an eluent E1; chloroform:methanol (95:5) as an eluent E2. The chromatograms were visualized using a UV lamp (LAMAG) at $254 \mathrm{~nm}$.

\section{Mass spectrometry measurements}

Mass spectrometric measurements were performed on a quadrupole time-of-flight (micrOTOF-Q) instrument (Bruker, Germany) equipped with an electrospray ionization source. The instrument was operated in the positive or negative ion mode and calibrated before each analysis with the Tunemix mixture (Bruker Daltonics) by a quadratic method. In the MS/MS experiments, the collision energy $(5-20 \mathrm{eV})$ was optimized for the best fragmentation. The solvent used for recording the mass spectra was acetonitrile:water:formic acid (50:50:0.1) mixture or methanol. The potential between the spray needle and the orifice was set to $4.5 \mathrm{kV}$. In the MS/MS mode, the quadrupole was used to select the precursor ions, which were fragmented in the hexapole collision cell generating product ions that were subsequently mass analyzed by the orthogonal reflectron TOF mass analyzer. For the collision-induced dissociation (CID) MS/MS measurements, the voltage over the hexapole collision cell varied from 15 to $30 \mathrm{~V}$ and argon was used as a collision gas.

\section{LC-MS}

The LC-MS analysis was performed on an Agilent 1200 HPLC system coupled to a micrOTOF-Q system mass spectrometer (Bruker Daltonics, Germany). Separation was carried out on an RP-Zorbax $(50 \times 2.1 \mathrm{~mm}, 3.5 \mu \mathrm{m})$ column with a gradient elution of $0-80 \% \mathrm{~B}$ in A (A, $0.1 \%$ $\mathrm{HCOOH}$ in water; $\mathrm{B}, 0.1 \% \mathrm{HCOOH}$ in acetonitrile) at room temperature (flow rate: $0.1 \mathrm{ml} / \mathrm{min}$ ) over $40 \mathrm{~min}$.

\section{Circular dichroizm}

The CD spectrum was recorded on a Jasco J-600 spectropolarimeter. Fmoc-Atda-OH was dissolved in methanol at a concentration of $0.07 \mathrm{mg} / \mathrm{ml}$. The spectrum of the solvent was recorded under identical conditions and subtracted during data analysis. A rectangular quartz cell of $1 \mathrm{~mm}$ pathlength was used. The data are presented as a mean residue molar ellipticity $[\Theta]$. The sample was measured in the range from 260 to $195 \mathrm{~nm}$.

\section{Results and discussion}

\section{Synthesis of Fmoc-Amda-OH (Fmoc-amino(2,5,5- trimethyl-1,3-dioxolan-2-yl)acetic acid)}

Herein we propose a new method for synthesis of an unnatural fully protected amino acid for the solid phase synthesis of carbonylated peptides according to the standard Fmoc protocol. So far, only one product, protected aminoadipic semialdehyde, which is a derivative of the oxidized lysine moiety, is commercially available. However, to the best of our knowledge, there are no reports on successful application of this derivative in the peptide synthesis. We performed the synthesis of a modified amino acid (fully protected, oxidized threonine), according to the scheme presented in Fig. 1a. After protecting the $\mathrm{N}$-amino and carboxylic groups, the side chain of threonine was oxidized using pyridinium chlorochromate (PCC) (Corey and Suggs 1975) for $24 \mathrm{~h}$ at room temperature. The alternative reagent that allows obtaining the same carbonylated compound was the $\mathrm{SO}_{3}$ /pyridine complex in DMSO. Our attempts at a direct synthesis of Fmoc-Amda-OH by oxidation of FmocThr-OH by PCC failed because of fast decarboxylation of the reaction product. Therefore, we examined the protection of the carbonyl group using ethylene glycol. After deprotection of the $\alpha$-amino and carboxylic groups by 
<smiles>CC(O)C(N)C(=O)OCc1ccccc1COC(=O)NC(C(=O)O)C(C)O</smiles>

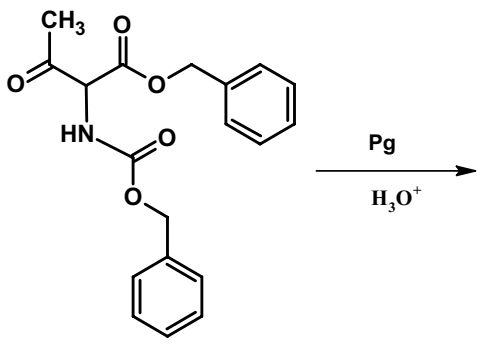

1<smiles>CC1(C(NC(=O)OCc2ccccc2)C(=O)OCc2ccccc2)OCCCO1</smiles>

2
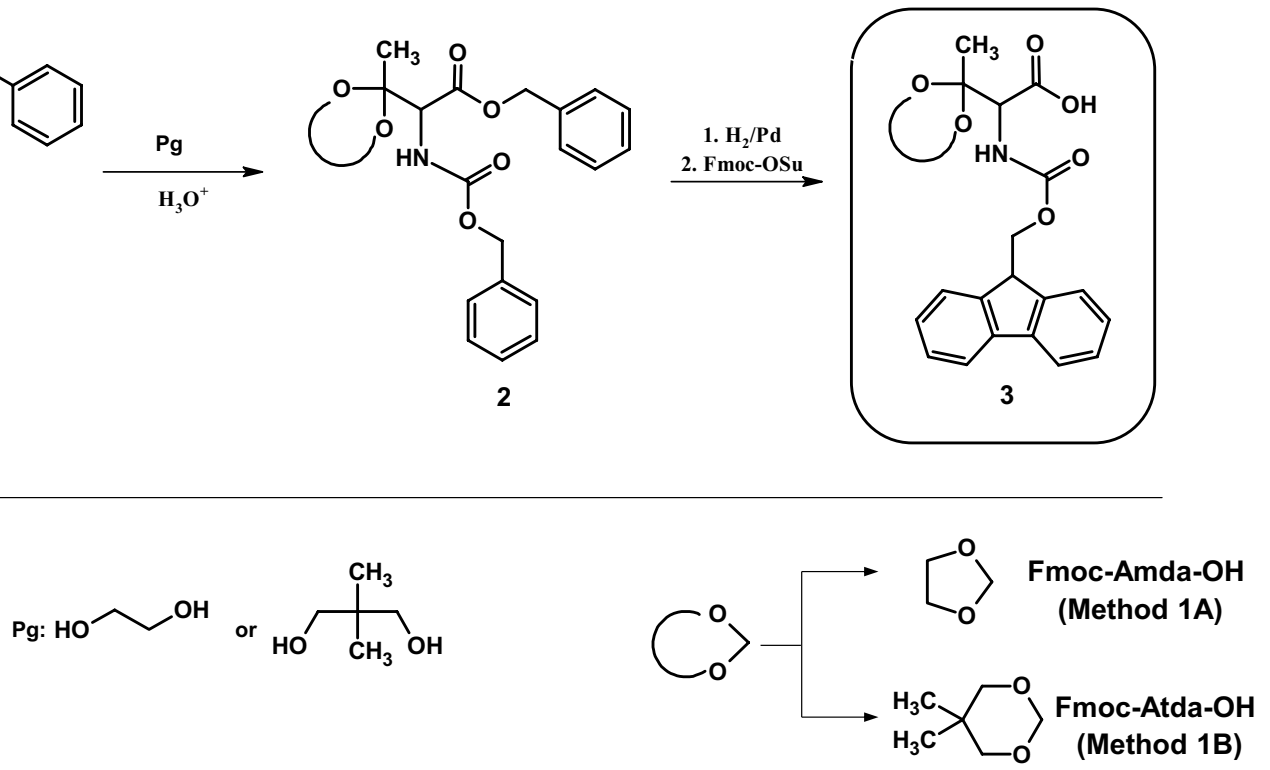

Fig. 1 Synthesis of Fmoc-Amda-OH (Method 1A) and Fmoc-Atda-OH (Method 1B)

catalytic hydrogenation in methanol, the Fmoc group was introduced. Our results show that synthesis of the oxidized derivative of threonine carried by the proposed method is feasible. In the ESI-MS spectrum of crude Fmoc-Amda$\mathrm{OH}$, a signal derived from the desired product is observed (Fig. S1A Supplementary Materials). The spectrum is dominated by two peaks. Next to the peak at $m / z$ 406.126, corresponding to the sodium adduct of a carbonylated amino acid, there is another peak at $\mathrm{m} / \mathrm{z} 334.105$. Our further studies revealed that this signal corresponds to Fmoc- $\beta$ Ala-OH. The yield of the desired product is relatively low while its retention time is close to that of the by-product (Fig. S1B Supplementary Materials).

The reaction product was purified by liquid chromatography on a silica gel, using $5 \%$ isopropanol in chloroform as an eluent. Unfortunately, separation of Fmoc-Amda-OH and Fmoc- $\beta$ Ala-OH on a preparative scale was not efficient because of coelution of these compounds (Fig. 2b). The ESI-MS spectrum (Fig. 2a) of the crude product is dominated by two peaks corresponding to Fmoc- $\beta$ Ala-OH and Fmoc-Amda-OH. The presented chromatograms (Fig. 2b) confirmed only the purity of the by-product.
Our investigations confirmed that the by-product obtained is Fmoc- $\beta$ Ala-OH. In the ESI-MS spectrum (Fig. S2A Supplementary Materials), only one peak corresponding to this product is observed. The structure of this compound was confirmed by NMR (Fig. S2B, S3, S4 Supplementary Materials). Obkircher et al. (2008) suggested previously that $\beta$-alanine may be formed by the Lossen rearrangement during the introduction of the Fmoc-protecting group.

As the yield of the synthesis was low and the separation of Fmoc-Amda-OH and Fmoc- $\beta$ Ala-OH on a preparative scale was not feasible, we decided to change the carbonyl group protection, therefore, a second synthetic strategy was proposed (Fig. 1b). This procedure included the same synthetic steps, but that time the carbonyl group was protected by 2,2-dimethylpropane-1,3-diol. According to the literature, this protecting group should be more labile at acidic conditions (Newmann and Harper 1958). We also expected that the new, more hydrophobic protection will facilitate chromatographic purification of the reaction product.

The result of the synthesis is presented in Fig. 3. In the ESI-MS spectrum, the signal of the desired product is observed. The product was successfully purified and only 


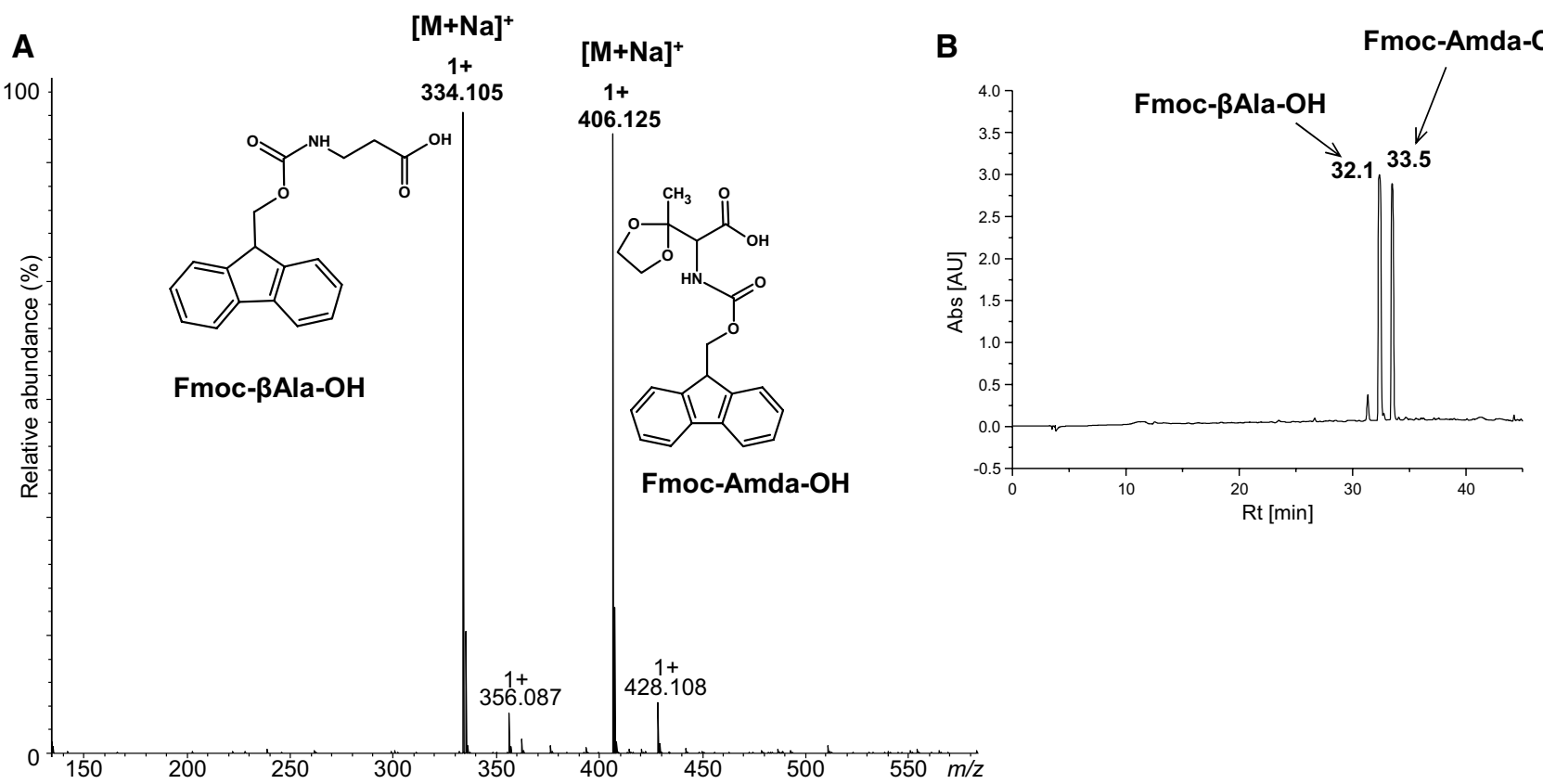

Fig. 2 ESI-MS spectrum (a) and chromatogram (b) of the purified product (Synthesis of Fmoc-Amda-OH Method 1A)
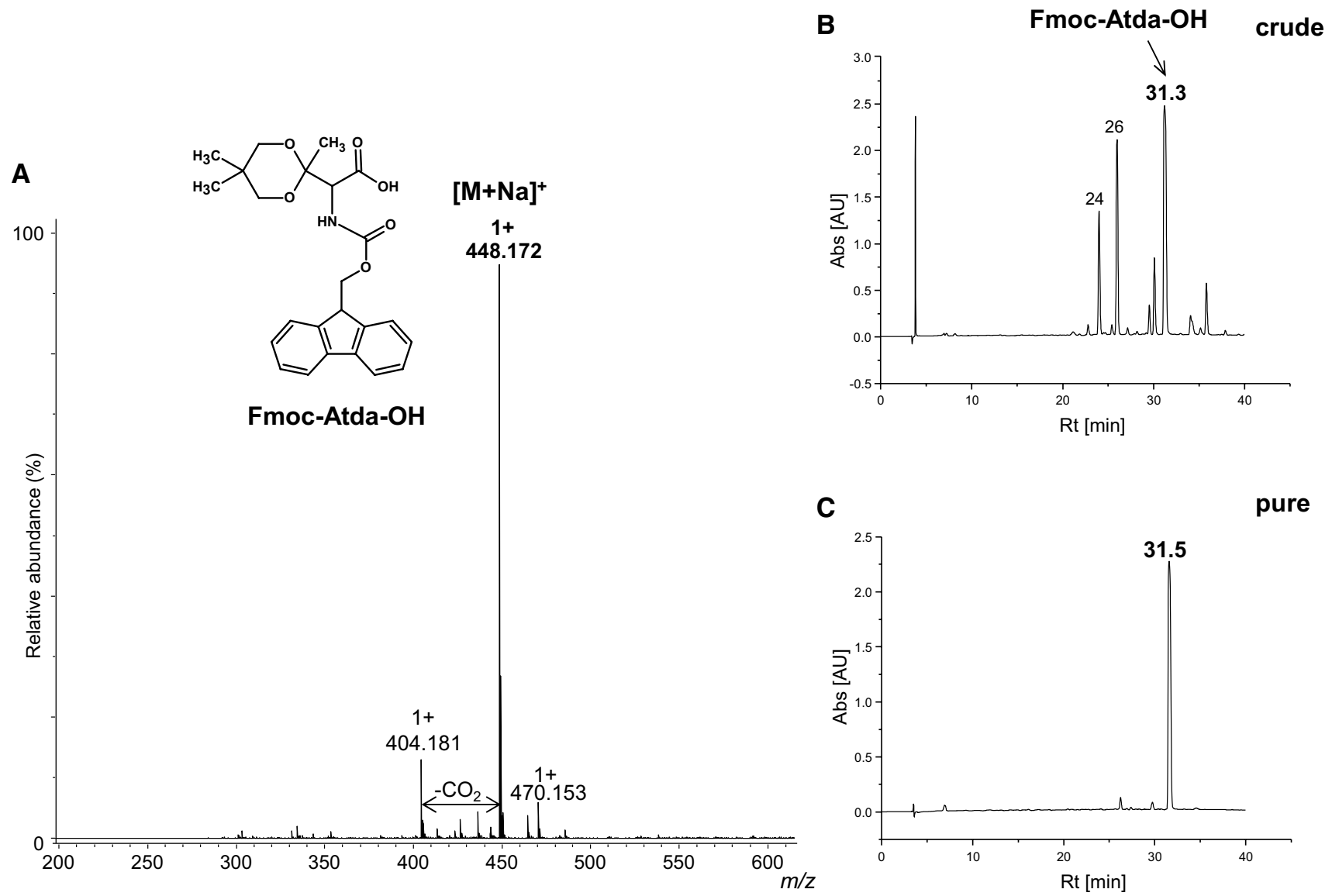

Fig. 3 ESI-MS (a) of pure Fmoc-Atda-OH; chromatogram of crude (b) and pure (c) product obtained by Method 1B 
Fig. 4 Synthesis of Fmoc-Atda$\mathrm{OH}$ (Method 2)

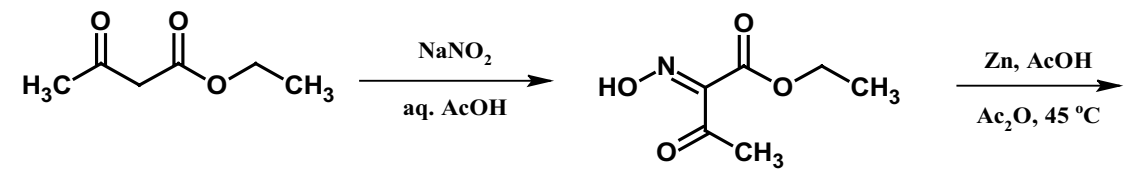<smiles>CCOC(=O)C(NC(C)=O)C(C)=O</smiles><smiles>CCOC(=O)C(NC(C)=O)C1(C)OCC(C)(C)CO1</smiles><smiles>CC1(C)COC(C)(C(N)C(=O)O)OC1</smiles><smiles></smiles><smiles>CC1(C)COC(C)(C(NC(=O)OCC2c3ccccc3-c3ccccc32)C(=O)O)OC1</smiles>

\section{Fmoc-Atda-OH}

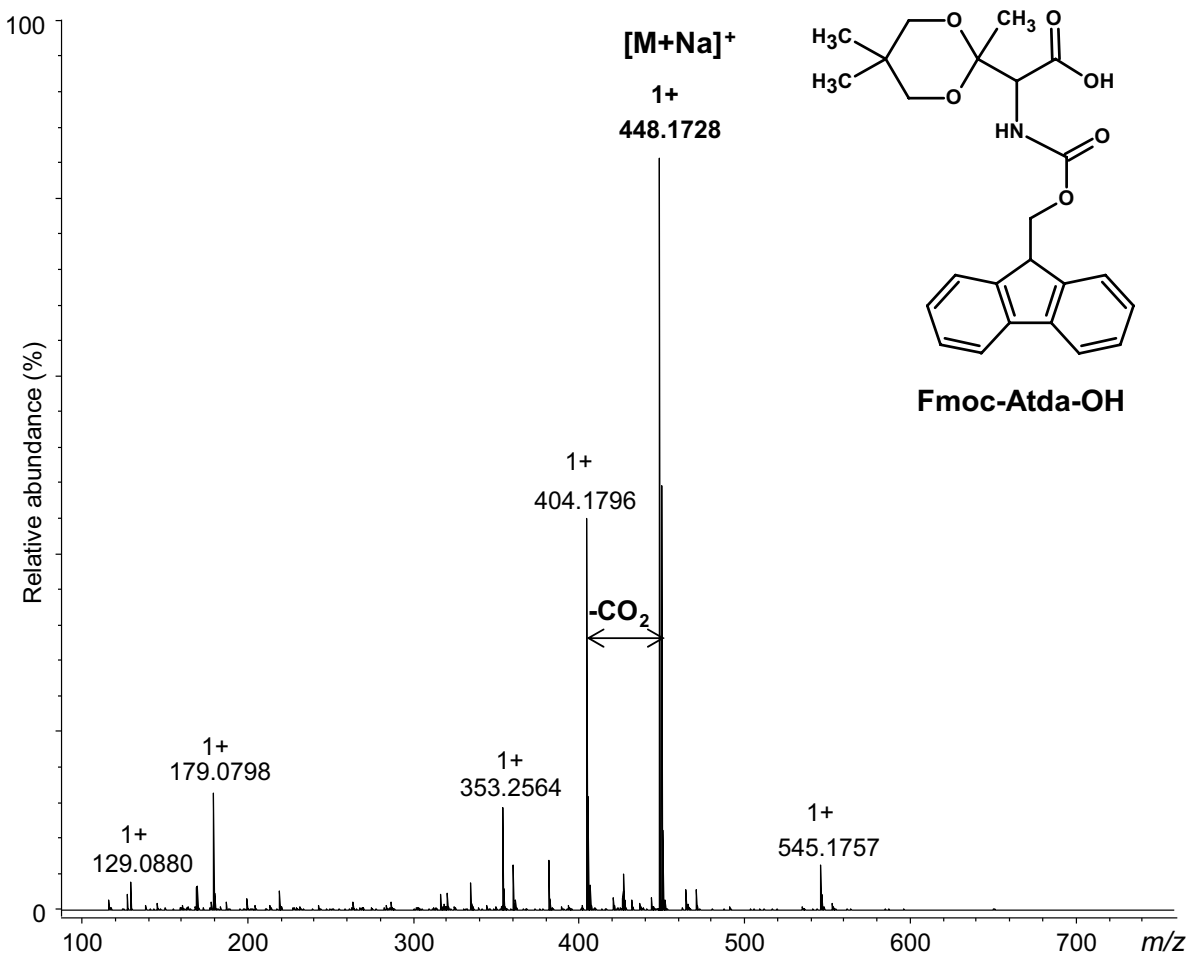

Fig. 5 ESI-MS of crude product Fmoc-Atda-OH obtained by Method 2 one peak corresponding to fully protected oxidized threonine is present in the chromatogram of the purified fraction. The structure of this building block was confirmed by
NMR (Fig. S5, S6 Supplementary Materials). During the synthesis of Fmoc-Atda-OH using 2,2-dimethylpropane1,3-diol as a protecting group, the amount of obtained 
Fmoc- $\beta$-Ala-OH was negligible. These data may be explained basing on the literature (Obkircher et al. 2008). The authors investigated the amount of Fmoc- $\beta$ Ala-OH formed from $\mathrm{Fmoc}-\mathrm{OSu}$, in relation to the amino acid residue being protected. It seems that the branched amino acids influence the formation of Fmoc- $\beta$ Ala-OH by-product during Fmoc protection reaction. The content of impurity depended on the amino acid structure and reaction conditions. The by-product was formed as result of Lossen rearrangement of succinimidyl moiety; however, the influence of amino acid structure on the Fmoc- $\beta$-Ala-OH content in the crude product was not completely resolved.

In addition, we designed another synthetic strategy utilizing ethyl acetoacetate. After nitrosylation of ethyl acetoacetate, the reduction in the presence of zinc dust and acetic acid combined with a direct acetylation was performed. It allows obtaining the ethyl ester of $N$-acetylated 2-amino-3-ketobutyric acid with a high yield and purity. The carbonyl group in the obtained product was protected using 2,2-dimethyl-propan-1,3-diol. Then, alkaline hydrolysis (3.5 M NaOH for $48 \mathrm{~h}$ ) was performed. Finally, the $\mathrm{N}$-amino group was protected by the Fmoc group. This synthetic pathway is presented in Fig. 4. Purity and identity of the product were confirmed by HPLC and HR-MS (Fig. 5). All the $m / z$ values were consistent with the calculated ones based on chemical formulas of the expected compounds. Based on the obtained analytical data, we proved that the desired product was obtained.

\section{Chirality}

${ }^{1} \mathrm{H}$ NMR experiments using Ac-Thr(O)-OEt were carried out in $\mathrm{D}_{2} \mathrm{O}$ and $\mathrm{CDCl}_{3}$, to check the dependence of the exchange rate of $\alpha$-hydrogen on solvent and time. The study revealed that the hydrogen-deuterium exchange was relatively fast. The peak corresponding to $\alpha$-hydrogen was not present in the ${ }^{1} \mathrm{H}$ NMR spectra obtained $3 \mathrm{~min}$ after dissolving the sample in $\mathrm{D}_{2} \mathrm{O}$, while the sample dissolved in de-acidified chloroform showed a doublet corresponding to $\alpha$-hydrogen (Fig. 6, S7 Supplementary Materials). This result reveals a lability of the $\alpha$-carbon proton which may be explained by formation of enolic form characteristic for dicarbonyl systems. Fmoc-Atda-OH was subjected to CD study. The CD spectrum presented in Fig. S8 (Supplementary Materials) did not show any ellipticity in the range from 260 to $190 \mathrm{~nm}$. Observed racemization is likely a result of planar enol formation.

\section{Synthesis of carbonylated peptides}

Pure, fully protected derivative of oxidized threonine (Fmoc-D,L-Atda-OH) was applied in the solid phase synthesis of carbonylated peptides. Peptides were prepared by manual solid phase technique using the standard Fmoc synthetic strategy with TBTU as a coupling reagent. The peptide was cleaved from the resin using TFA/water/TIS (95:2.5:2.5, v/v).

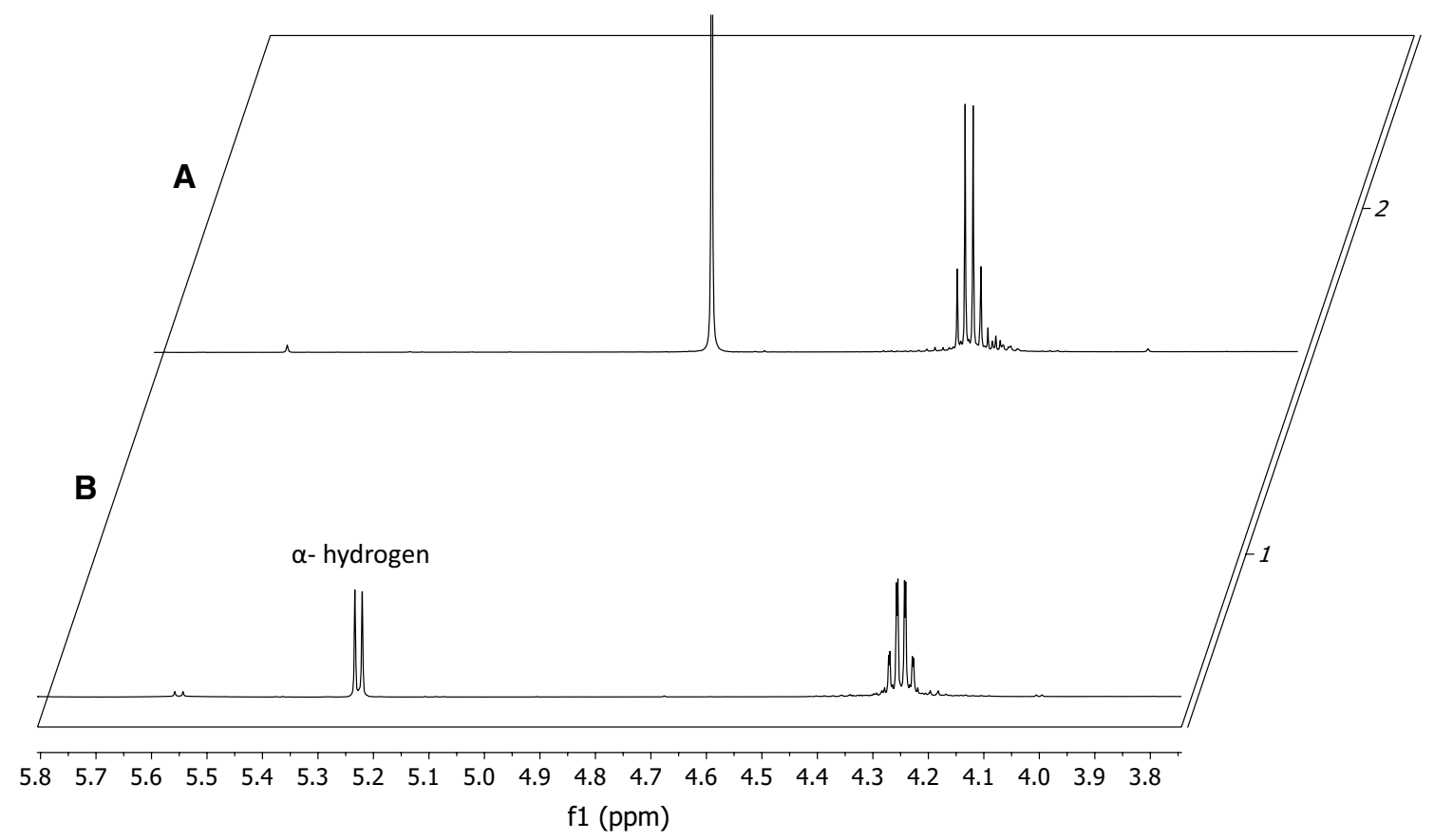

Fig. $6{ }^{1} \mathrm{H}$ NMR spectra of Ac-Thr(O)-OEt measured in: $a \mathrm{D}_{2} \mathrm{O}$ after 3 min; $b \mathrm{CDCl}_{3}$ 

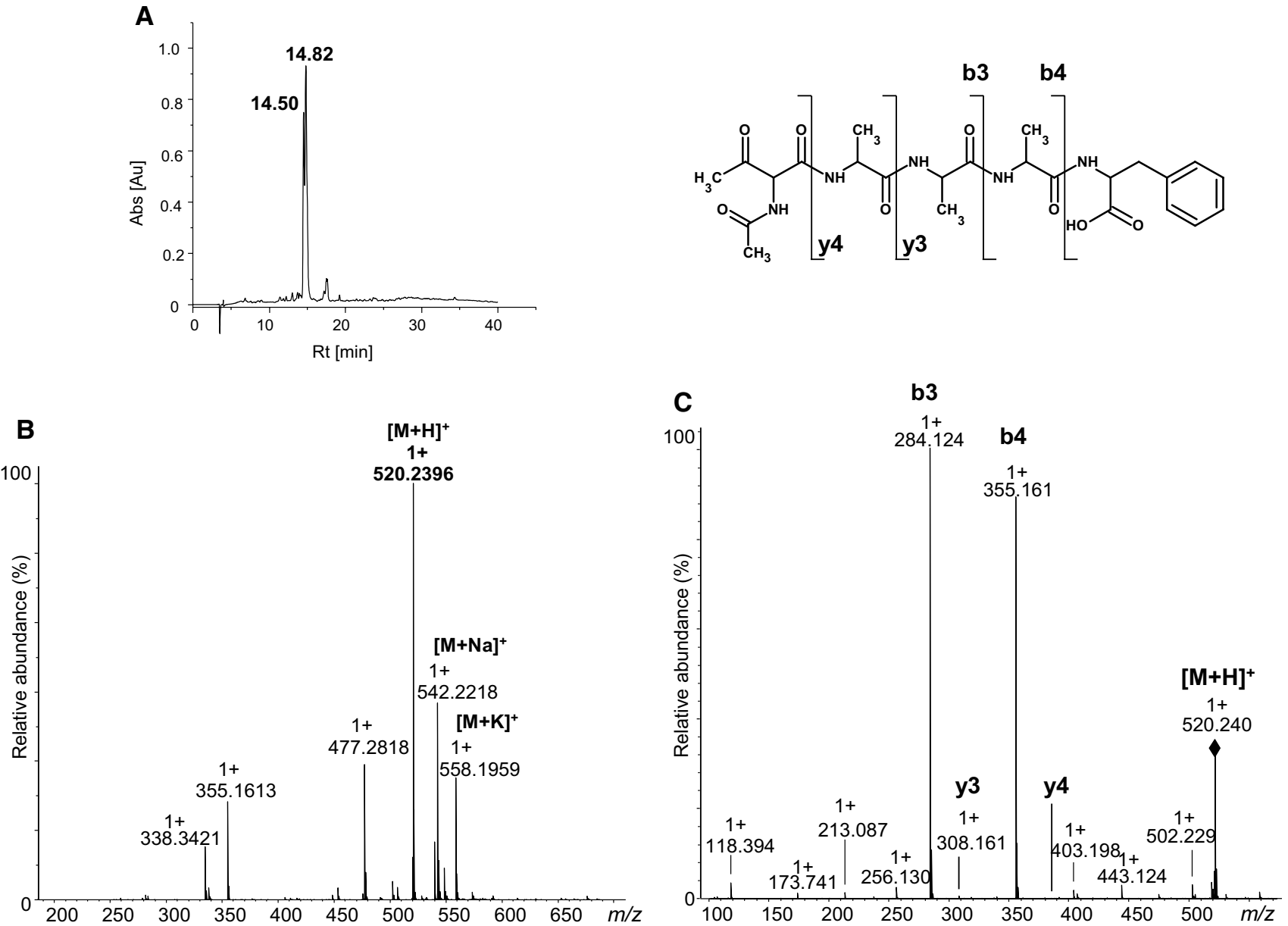

Fig. 7 Analytical data of Ac-Thr(O)-Ala-Ala-Ala-Phe-OH (Method 2). a Chromatogram; b ESI-MS spectrum; c ESI-MS/MS spectrum

A series of synthetic model peptides containing the building block (H-Thr(O)-Ala-Phe-OH, H-Thr(O)-Ala-Ala-AlaPhe-OH, Ac-Thr(O)-Ala-Ala-Ala-Phe-OH, H-Gly-Thr(O)Ala-Ala-Ala-Phe-OH, H-Leu-Val-Asn-Glu-Val-Thr(O)-GluPhe-Ala-Lys-OH) were synthesized. To make this model more realistic, we based the sequence of one peptide on a fragment of naturally occurring protein (tryptic fragment [6675] HSA containing Thr residue). The oxidized threonine residue replaces a threonine residue in a natural protein giving the sequence: H-Leu-Val-Asn-Glu-Val-Thr(O)-Glu-Phe-AlaLys-OH. The influence of position of the unnatural amino acid in the peptide chain on efficiency of deprotection of the carbonyl group was studied. In the case of application of 2,2-dimethylpropane-1,3-diol as a protecting group, we found that incorporation of a carbonylated amino acid at the N-terminus does not allow removal of the masking group even after $24 \mathrm{~h}$ incubation. However, the elongation of carbonylated peptide (H-Gly-Thr(O)-Ala-Ala-Ala-Phe-OH) or acetylation of the N-terminus (Ac-Thr(O)-Ala-Ala-Ala-Phe-OH) allowed a complete removal of the protecting group from carbonyl in $3 \mathrm{~h}$ (Fig. 7a). Application of this derivative resulted in obtaining of the carbonylated peptides with a $90 \%$ yield. A signal of the protonated, carbonylated peptide is observed in the MS spectrum of the crude product (Fig. 7b). The parent ion at $\mathrm{m} / z$ 520.239, was subjected to MS/MS fragmentation. The fragmentation spectrum is dominated by a series of $b$ and $\mathrm{y}$ ions covering the whole sequence of the peptide (Fig. 7c, S9 Supplementary Materials). In the chromatogram of a pure carbonylated peptide, two signals corresponding to diastereomers were observed because of racemization.

We also performed a successful synthesis of a tryptic fragment [66-75] HSA containing carbonylated threonine (H-Leu-Val-Asn-Glu-Val-Thr(O)-Glu-Phe-Ala-Lys-OH). The ESI-MS and ESI-MS/MS spectra, and the HPLC chromatogram of pure H-Leu-Val-Asn-Glu-Val-Thr(O)Glu-Phe-Ala-Lys-OH are presented (Fig. S10 Supplementary Materials).

In the synthesis, we applied a racemic derivative FmocD,L-Atda-OH, obtaining a mixture of diastereoisomeric peptides. However, the composition of this product is a matter of equilibrium and does not depend on the chirality of applied substrate (Fmoc-Atda-OH). 
A

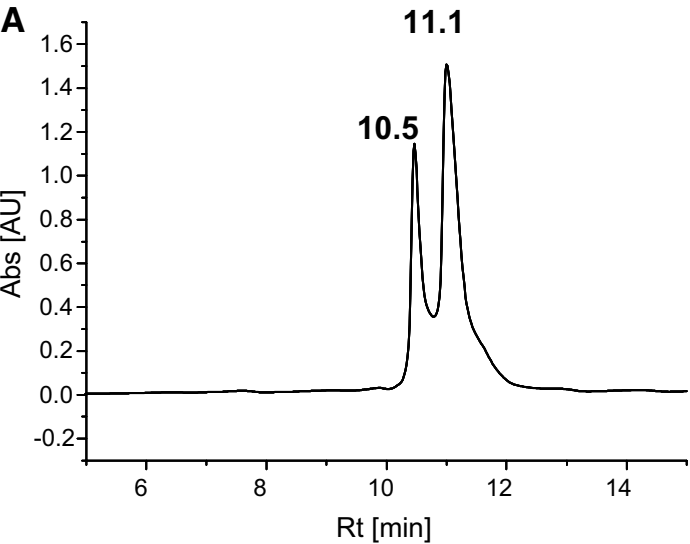

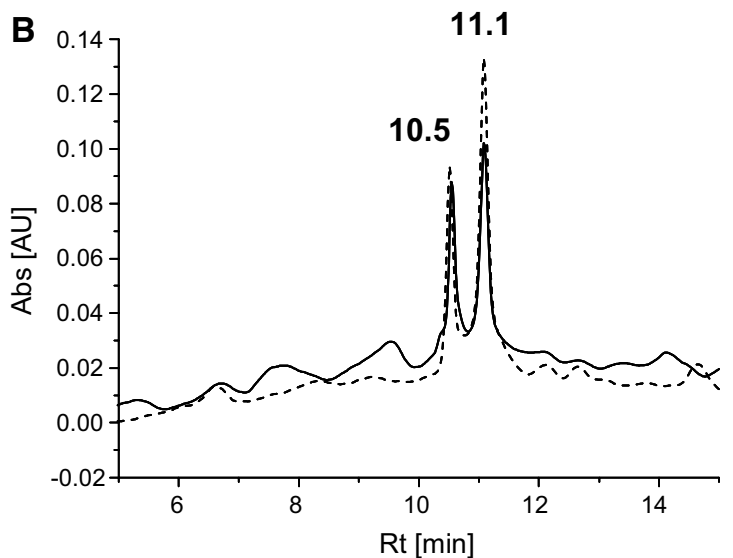

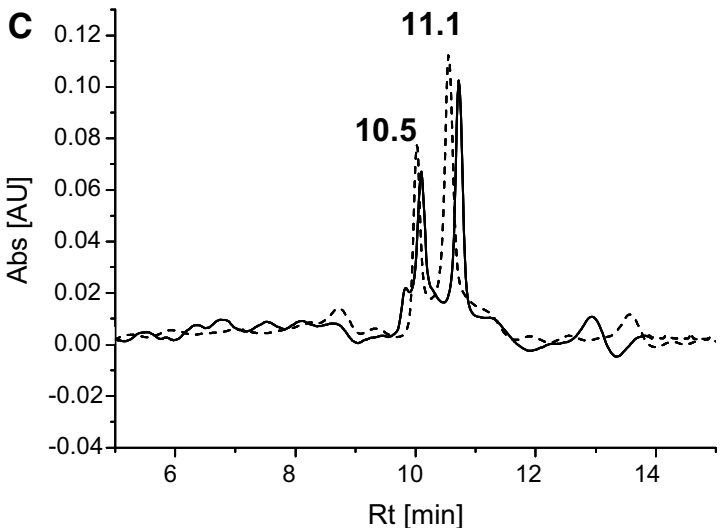

Fig. 8 a Chromatogram of pure H-Leu-Val-Asn-Glu-Val-Thr(O)Glu-Phe-Ala-Lys-OH; b chromatograms of fractions corresponding to each peak reanalyzed $30 \mathrm{~min}$ after separation (solid line the fraction eluted at $10.5 \mathrm{~min}$; dotted line the fraction eluted at $11.1 \mathrm{~min}$ );

We tested a progress of racemization as a function of time for peptide H-Leu-Val-Asn-Glu-Val-Thr(O)-GluPhe-Ala-Lys-OH using HPLC. Two signals corresponding to two isomeric forms of the pure peptide are observed in the chromatogram (Fig. 8a). The fractions corresponding to both peaks were collected and subjected to re-analysis of purity at the same conditions. The obtained chromatograms showed that two isomeric forms appeared after less than 30 min (Fig. 8b). The HPLC analysis executed after $24 \mathrm{~h}$ for the separated signals showed the same peak areas (Fig. 8c).

LC-MS analysis confirmed that two peaks in the chromatogram correspond to compounds with the same molecular weight (Fig. 9). The resolution of the column used for LC was not sufficient to completely separate these two signals. However, the presented spectra (Fig. 9a, b) revealed unquestionably the same $\mathrm{m} / \mathrm{z}$ for the appropriate parts of peaks. Additionally, the extracted ion chromatogram was generated by Data Analysis program and exactly the same profile of the chromatogram was obtained. In the chromatogram (Figs. 8, 9), the peaks corresponding to two c chromatograms of fractions corresponding to each peak reanalyzed $24 \mathrm{~h}$ after separation (solid line the fraction eluted at $10.5 \mathrm{~min}$; dotted line the fraction eluted at $11.1 \mathrm{~min}$

diastereoisomeric forms of modified peptides are characterized by broadening and tailing. These features additionally confirmed our results concerning the fast equilibrium between both stereoisomeric peptides. Based on the NMR study, we confirmed the exchange rate of $\alpha$-hydrogen. Theoretically, the effect may result from the presence of an enol form. Additionally, the cis-/trans-isomerizatiom on the peptide bond may contribute to a further peak boarding; however, a thorough investigation is needed to confirm this speculation.

We also applied a crude, fully protected amino acid containing ethylene glycol as a protection of the carbonyl group (Fmoc-Amda-OH) for the solid phase synthesis of carbonylated peptides. Peptides were prepared as previously described. Our results indicate that Fmoc-Amda-OH was also successfully incorporated into model peptides. The ESI-MS spectrum of crude product Ac- $\mathrm{Thr}(\mathrm{O})$-Ala-AlaAla-Phe-OH is presented (Fig. S11 Supplementary Materials). In the spectrum, three main peaks correspond to the protonated peptides containing $\beta$-alanine, $\operatorname{Thr}(\mathrm{O})$, and Amda [protected $\operatorname{Thr}(\mathrm{O})]$. After extending the time of cleavage of 

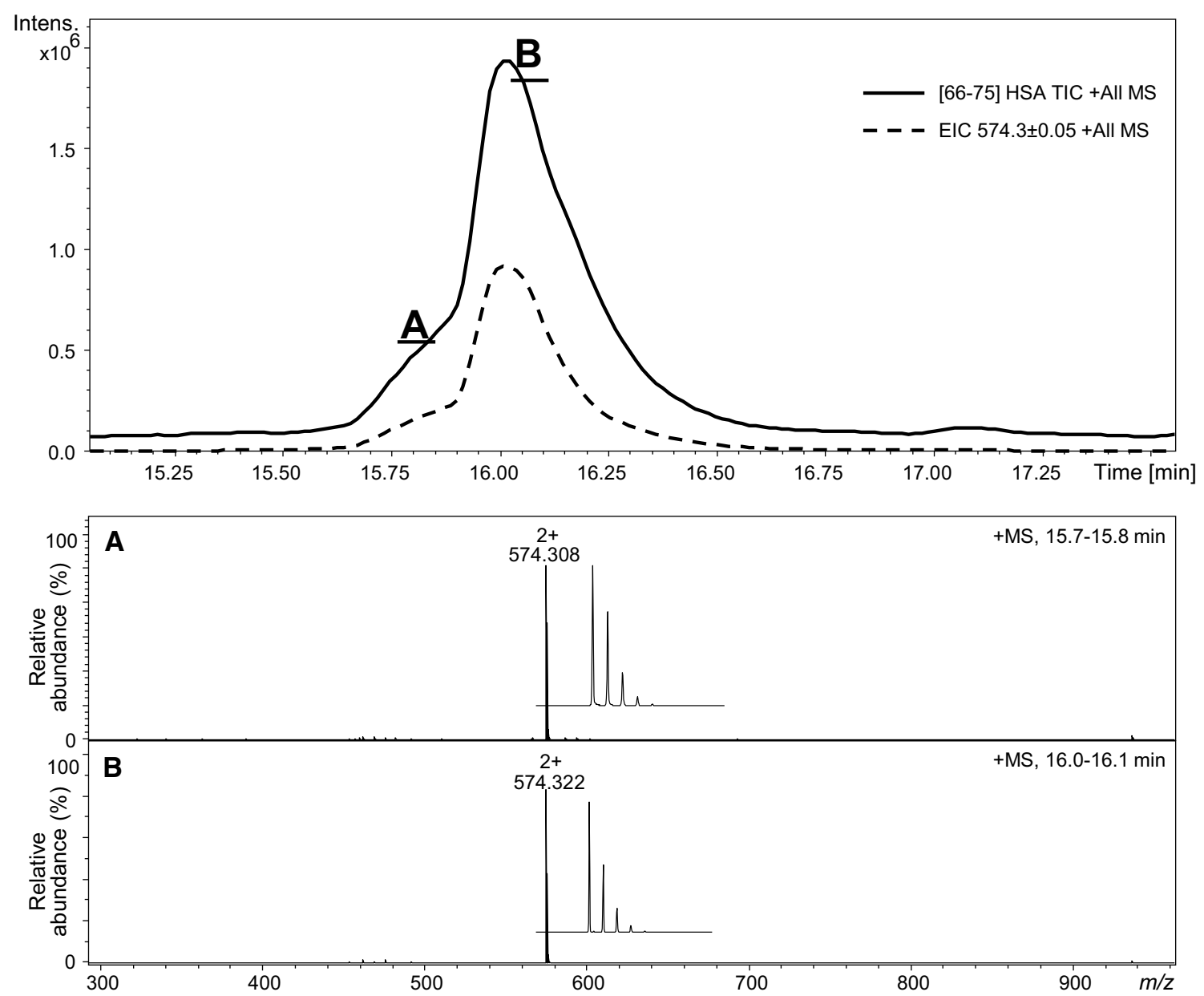

Fig. 9 LC-MS of pure HSA [66-75]; a ESI-MS of the peptide eluted at 15.7-15.8 min; b ESI-MS of the peptide eluted at 16.0-16.1 min

the peptide, the deprotection was complete (see below) and the signal at $\mathrm{m} / \mathrm{z} 564.267$ was not observed. We found that incorporation of a carbonylated amino acid at the $\mathrm{N}$-terminus does not allow removing the acetal group even after $24 \mathrm{~h}$ of incubation, in the mixture used for cleavage or microwaveassisted TFA (Kluczyk et al. 2010) cleavage from the resin. The probable reason is the proximity of the amino group which easily gets protonated. The positive charge on the nitrogen prevents protonation of acetal oxygen because of possible electrostatic repulsion. The elongation of peptide at the $\mathrm{N}$-terminus allowed the removal of the acetal group after $8 \mathrm{~h}$ of incubation. Acetylation of the $\mathrm{N}$-terminal amino group decreased the time of complete cleavage to $4 \mathrm{~h}$. The purity of synthesized peptides was checked by HPLC. The chromatograms of the crude product after various times of cleavage are presented (Fig. S12A Supplementary Materials). As one can see, after $4 \mathrm{~h}$ of incubation, the acetal group is completely removed from the carbonyl group. Two main products of synthesis were successfully separated using HPLC. The chromatograms of pure compounds are presented (Fig. S12B and C Supplementary Materials).
We observed the racemization also in the case of Fmoc-Amda-OH synthesis. The racemization is a result of chemical structure of oxidized threonine derivative. The proton at $\alpha$ carbon is activated by two carbonyl groups and undergoes fast exchange. The chromatograms of crude and pure carbonylated peptides $(\mathrm{Ac}-\mathrm{Thr}(\mathrm{O})$-Ala-Ala-AlaPhe-OH) prepared by solid phase synthesis using crude Fmoc-Amda-OH were placed in Supplementary Materials (Fig. S12A and C Supplementary Materials). Two fractions corresponding to these signals were collected and analyzed by mass spectrometry, showing the same molecular mass, which is in good agreement with assumption that $\operatorname{Thr}(\mathrm{O})$ residue is susceptible to racemization.

\section{Conclusions}

We designed a straightforward and convenient method of synthesis of the fully protected carbonylated building block Fmoc-Atda-OH. Two different protections of the carbonyl group were tested. The application of 
2,2-dimethylpropane-1,3-diol results in a better yield and purity of the fully protected building block as compared to ethylene glycol. The crude Fmoc-Amda-OH and pure Fmoc-Atda-OH were successfully applied in the solid phase synthesis of carbonylated peptides. The kinetics of the carbonyl group deprotection with respect to the position of carbonylated amino acid residue in the peptide chain was investigated, revealing that peptides with N-terminal $\operatorname{Thr}(\mathrm{O})$ are not susceptible to deprotection with trifluoroacetic acid. In addition, the main by-product (Fmoc$\beta$ Ala-OH) formed during Fmoc-Amda-OH was identified.

Acknowledgments This work was supported by a Grant No UMO2012/07/D/ST5/002324 from the Polish National Science Centre.

Conflict of interest The authors declare that they have no conflict of interest.

Open Access This article is distributed under the terms of the Creative Commons Attribution License which permits any use, distribution, and reproduction in any medium, provided the original author(s) and the source are credited.

\section{References}

Bollineni RC, Fedorova M, Hoffmann R (2011a) Identification of carbonylated peptides by tandem mass spectrometry using a precursor ion-like scan in negative ion mode. J Proteomics 74:23512359. doi:10.1016/j.jprot.2011.05.033

Bollineni RC, Hoffmann R, Fedorova M (2011b) Identification of protein carbonylation sites by two-dimensional liquid chromatography in combination with MALDI- and ESI-MS. J Proteomics 74:2338-2350. doi:10.1016/j.jprot.2011.07.002

Buré C, Marceau P, Meudala H, Delmasa AF (2012) Synthesis and analytical investigation of C-terminally modified peptide aldehydes and ketone: application to oxime ligattion. J Pept Sci 18:147-154. doi:10.1002/psc. 1429

Chan WC, White PD (2000) Fmoc solid phase peptide synthesis. Oxford University Press, USA

Corey EJ, Suggs W (1975) Pyridinium chloroformate. An efficient reagent for oxidation of primary and secondary alcohols to carbonyl compounds. Tetrahedron Lett 16:2647-2650. doi:10.1016/ S0040-4039(00)75204-X

Dalle-Donne I, Scaloni A, Giustarini D, Cavarra E, Tell G, Lungarella G, Colombo R, Rossi R, Milzani A (2005) Proteins as biomarkers of oxidative/nitrosative stress in diseases: the contribution of redox proteomics. Mass Spectrom Rev 24:55-99. doi:10.1002/mas.20006

Dalle-Donne I, Rossi R, Ceciliani F, Giustarini D, Colombo R, Milzani A (2006) Proteins as sensitive biomarkers of human conditions associated with oxidative stress. In: Dalle-Donne I, Scaloni A, Butterfield DA (eds) Redox Proteomics. John Wiley \& Sons, New Jersey, pp 487-525

Green TW, Wuts PGM (1999) Protective groups in organic synthesis. Wiley-Interscience, New York

Grimsrud PA, Xie H, Griffin TJ, Bernlohr DA (2008) Oxidative stress and covalent modification of protein with bioactive aldehydes. J Biol Chem 283:21837-21841. doi:10.1074/jbc.R700019200

Kijewska M, Stefanowicz P, Kluczyk A, Szewczuk Z (2011) The isotopic exchange of oxygen as a tool for detection of the glycation sites in proteins. Anal Biochem 419:81-87. doi:10.1016/j. ab.2011.08.040
Kluczyk A, Rudowska M, Stefanowicz P, Szewczuk Z (2010) Microwave-assisted TFA cleavage of peptides from Merrifield resin. J Pept Sci 16:31-39. doi:10.1002/psc.1191

Lee S, Young Nicolas L, Whetstone Paul A, Cheal Sarah M, Benner WH, Lebrilla Carlito B, Meares Claude F (2006) Method to site-specifically identify and quantitate carbonyl end products of protein oxidation using oxidation-dependent element coded affinity tags (O-ECAT) and nanoliquid chromatography Fourier transform mass spectrometry. J Proteome Res 5:539-547. doi:10.1021/pr050299q

Madian GA, Regnier FE (2010a) Protein carbonylation and their oxidation sites. J Proteome Res 9:3766-3780. doi:10.1021/ pr1002609

Madian GA, Regnier FE (2010b) Profiling carbonylated proteins in human plasma. J Proteome Res 9:1330-1343. doi:10.1021/ pr900890k

Marceau P, Buré C, Delmas AF (2005) Efficient synthesis of C-terminal modified peptides ketone for chemical ligation. Bioorg Med Chem Lett 15:5442-5445. doi:10.1016/j.bmcl.2005.08.105

Mirzaei H, Regnier F (2006) Enrichment of carbonylated peptides using girard $\mathrm{P}$ reagent and strong cation exchange chromatography. Anal Chem 78:770-778. doi:10.1021/ac0514220

Mirzaei H, Baena B, Barbas C, Regnier F (2008) Identification of oxidized proteins in rat plasma using avidin chromatography and tandem mass spectrometry. Proteomics 8:1516-1527. doi:10.1002/pmic.200700363

Moller IM, Rogowska-Wrzesińska A (2011) Protein carbonylation and metal-catalyzed protein oxidation in a cellular perspective. J Proteomics 11:2228-2242. doi:10.1016/j.jprot.2011.05.004

Newmann MS, Harper RJ (1958) Kinetic and equilibrium studies of cyclic ketal formation and hydrolysis. J Am Chem Soc 80:6350 6355. doi:10.1021/ja01556a047

Obkircher M, Stächelin C, Dick F (2008) Formation of Fmoc- $\beta$ alanine during Fmoc-protections with Fmoc-Osu. J Pept Sci 14:763-766. doi:10.1002/psc.1001

Palmese A, De Rosa C, Marino G, Amoresano A (2011) Dansyl labeling and bidimensional mass spectrometry to investigate protein carbonylation. Rapid Commun Mass Spectrom 25:223-231. doi: $10.1002 / \mathrm{rcm} .4863$

Requena JR, Chao CC, Levine RL, Stadtman ER (2001) Glutamic and aminoadipic semialdehydes are the main carbonyl products of metal-catalyzed oxidation of proteins. Proc Natl Acad Sci USA 98:69-74. doi:10.1073/pnas.98.1.69

Roe MR, McGowan TF, Thompson LV, Griffin TJ (2010) Targeted 180-labeling for improved proteomic analysis of carbonylated peptides by mass spectrometry. J Am Soc Mass Spectrom 21:1190-1203. doi:10.1016/j.jasms.2010.03.029

Smith CD, Carney JM, Starke-Reed PE, Oliver CN, Stadtman ER, Floyd RA et al (1991) Excess brain protein oxidation and enzyme dysfunction in normal aging and in Alzheimer disease. Proc Natl Acad Sci USA 88:10540-10543

Stadtman ER, Levine RL (2003) Free radical-mediated oxidation of free amino acids and amino acid residues in proteins. Amino Acids 25:207-218. doi:10.1007/s00726-003-0011-2

Stefanowicz P, Kijewska M, Kapczyńska K, Szewczuk Z (2010) Methods of site-selective solid phase synthesis of peptide-derived Amadori products. Amino Acids 38:881-889. doi:10.1007/s00726-009-0294-z

Telci A, Cakatay U, Kayali R, Erdogan C, Orhan Y, Sivas A et al (2000) Oxidative protein damage in plasma of type 2 diabetic patients. Horm Metab Res 32:40-43. doi:10.1055/s-2007-978584

Uttara B, Singh AV, Zamboni P, Mahajan RT (2009) Oxidative stress and neurodegenerative diseases: a review of upstream and downstream antioxidant therapeutic options. Curr Neuropharmacol 7:65-74. doi:10.2174/157015909787602823 